\title{
1 Mechanistic study to investigate the effects of different gas 2 injection scenarios on the rate of asphaltene deposition: An 3 experimental approach
}

Hossein Dashti ${ }^{a, b, 1}$, Peyman Zanganeh ${ }^{c, 1}$, Shahin Kord ${ }^{d}$, Shahab Ayatollahi ${ }^{e, *}$, Amirpiran

Amiri $^{f}$

${ }^{a}$ School of Chemical Engineering, The University of Queensland, Brisbane, Australia

${ }^{b}$ Centre for Coal Seam Gas, The University of Queensland, Brisbane, Australia

${ }^{\mathrm{c}}$ Department of Chemical Engineering, School of Chemical Engineering, Shahid Bahonar University of Kerman, Kerman, Iran

${ }^{d}$ Ahwaz Faculty of Petroleum, Petroleum University of Technology (PUT), Ahwaz, Iran

${ }^{\mathrm{e}}$ Sharif Upstream Petroleum Research Institute, Department of Chemical and Petroleum Engineering, Sharif University of Technology, Tehran, Iran

${ }_{\mathrm{f}}^{\mathrm{f}}$ European Bioenergy Research Institute (EBRI), School of Engineering and Applied Science, Aston University, Birmingham, B4 7ET, United Kingdom

${ }^{1}$ The first two authors contributed equally to this work.

${ }^{*}$ Corresponding author, Email: shahab@ sharif.ir, Tel/Fax: +98 2166166411

\section{Abstract}

20 Asphaltene deposition during enhanced oil recovery (EOR) processes is one of the most 21 problematic challenges in the petroleum industry, potentially resulting in flow blockage. Our 22 understanding of the deposition mechanism with emphasis on the rate of the asphaltene deposition 23 is still in its infancy and must be developed through a range of experiments and modelling studies.

24 This study aims to investigate the rate of asphaltene deposition through a visual study under 25 different gas injection scenarios. To visualise the asphaltene deposition, a high-pressure setup was 26 designed and constructed, which enables us to record high-quality images of the deposition process 27 over time. Present research compares the effects of nitrogen $\left(\mathrm{N}_{2}\right)$, carbon dioxide $\left(\mathrm{CO}_{2}\right)$ and methane $\left(\mathrm{CH}_{4}\right)$ on the rate of asphaltene deposition at different pressures. The experimental results

29 in the absence of gas injection revealed that the rate of asphaltene deposition increases at higher

30 pressures. The results showed that the rate of asphaltene deposition in the case of $\mathrm{CO}_{2}$ injection is

311.2 times faster than $\mathrm{CH}_{4}$ injection at 100 bar pressure. However, $\mathrm{N}_{2}$ injection has less effect on

32 the deposition rate. Finally, it has been concluded that the injection of $\mathrm{CO}_{2}$ leads to more asphaltene

33 deposition in comparison with $\mathrm{CH}_{4}$ and $\mathrm{N}_{2}$. Moreover, the experimental results confirmed that gas

34 injection affects the mechanism of asphaltene flocculation and leads to the formation of bigger 
flocculated asphaltene particles. The findings of this study can help for a better understanding of

36 the mechanism of the asphaltene deposition during different gas-EOR processes.

Keywords: Enhanced oil recovery, asphaltene deposition rate, $\mathrm{CO}_{2}$ injection, gas injection

\section{Introduction}

Asphaltenes are heavy crude oil fractions that are not soluble in light hydrocarbon solvents (typically n-pentane or n-heptane) but could be dissolved in light aromatic hydrocarbons (typically toluene) $[1,2]$. Asphaltenes are the most polar components and have the highest molecular weight among crude oil fractions, exhibiting both aliphatic and aromatic structures [3-6]. Asphaltene particles tend to aggregate and produce more massive particles [7]. The complex physical and chemical properties of asphaltenes remain a challenge for the research community [8,9]. Changes in pressure, temperature or composition cause the resin layer to shrink followed by asphaltene precipitation [10-13]. The reversibility or irreversibility of the asphaltene precipitation is not fully understood in the literature, and it is likely to be related to the complex structure of the asphaltene particles $[7,14,15]$.

In order to establish consistent terminology, it is necessary to clarify the application of different terms. The terms "aggregation" and "flocculation" have been used to refer to the formation of the clusters of asphaltene particles in the crude oil which will result in increasing the size of the small asphaltene particles from nanometer into micrometre length scale [16]. The term "precipitation" is defined in its broadest sense to refer to the whole process of asphaltenes flocculation or aggregation from the crude oil fluid. Finally, "deposition" refers to the settling of the aggregated or flocculated asphaltene particles onto the solid surface which is mostly investigated in this work. Asphaltene deposition in wellbores and pipelines is a technical and operation concern at various stages of oil production and processing. This problematic phenomenon has not been well understood yet mainly because of complex physicochemical properties and phase behaviour. In particular, there is a critical gap in understanding the conditions that lead to asphaltene instability [17]. Such insight into the problem physics guides engineers and operators to design and implement appropriate strategies toward an asphaltene-free operation. Asphaltene deposition can occur in the first stage of oil production or during enhanced oil recovery (EOR) [18]. Asphaltene 
65 deposition in oil reservoirs can lower its permeability, change rock wettability from water-wet to 66 oil-wet, and increase hydrocarbon viscosity. All of these negative impacts lead to an ongoing 67 decline in oil production rate $[19,20]$. Numerous research has shown that the tendency of 68 asphaltene particles to deposit is strongly related to the complex structure of asphaltenes [19, 2169 23]. The lost production due to asphaltene deposition is estimated to be approximately $\$ 1,200,000$ 70 per day [24]. Accordingly, asphaltene deposition can be avoided/minimised by manipulating the 71 structure via the treatment or prevention methods [25]. The treatment approaches, however, are 72 expensive causing process economic concerns. The possible solution for the problem of the 73 asphaltene deposition in the oil reservoirs compared with the expensive treatments methods to 74 remove the asphaltenes can be using inhibitors [26-29] or control the operation conditions [22, 23, 75 30-32]. Fig. 1 presents a schematic of the problem of asphaltene deposition with possible solutions. 76 EOR methods are the most common approaches after primary and secondary oil production [3377 37]. A growing body of literature recognises the importance of EOR processes and enhancing the 78 effectiveness of these methods [38-44]. Carbon dioxide $\left(\mathrm{CO}_{2}\right)$, nitrogen $\left(\mathrm{N}_{2}\right)$ and methane $\left(\mathrm{CH}_{4}\right)$ 79 flooding are commonly considered as EOR methods. Asphaltene deposition during EOR processes 80 is one of the challenges facing the oil industry. Asphaltene deposition during $\mathrm{CO}_{2}$ flooding in oil 81 reservoirs has been extensively studied [21-23, 31, 32, 45-48]. However, few studies have been 82 conducted examining the influence of $\mathrm{N}_{2}$ and $\mathrm{CH}_{4}$ flooding on the amount of asphaltene deposition 83 [23, 49-53]. 


\section{Gas Injection in Enhanced Oil Recovery}

Problem
Asphaltene deposition during
different gas-EOR methods
which decreases oil production
rate

\section{Problem}

Asphaltene deposition during different gas-EOR methods rate

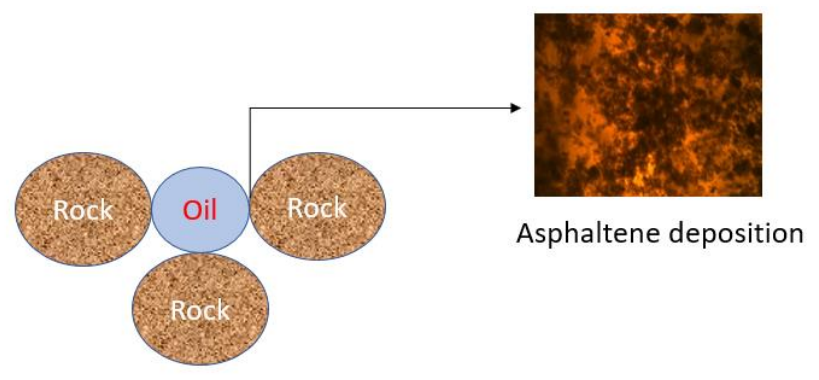

\section{Solution}

Control the operating conditions by understanding the mechanism of asphaltene deposition

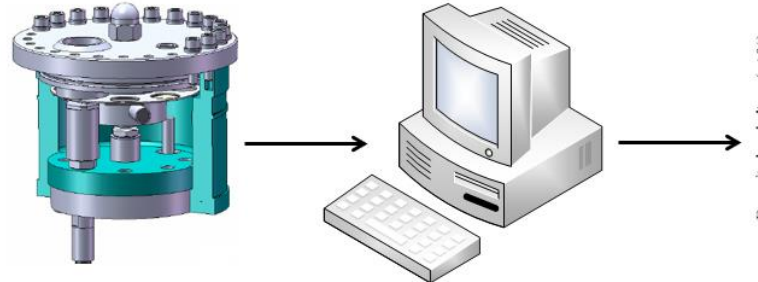

Experimental tests

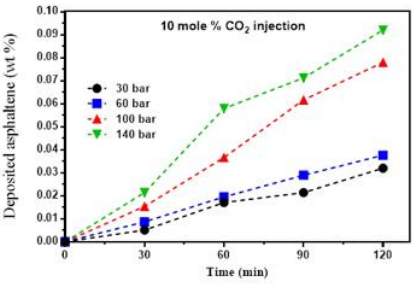

Control the operating conditions

Fig. 1. Schematic of the problem of asphaltene deposition in the oil reservoirs.

The kinetics of asphaltene deposition is an area of intense debate in the research community. Although extensive research has been conducted on asphaltene aggregation kinetics and thermodynamic stability, few studies have focused on the rate of asphaltene deposition. Previous reports indicate that the process of asphaltene deposition near the wellbore region primarily

91 depends on the rate of the process [54]. The slow kinetics of asphaltene deposition is an obstacle

92 to understanding asphaltene behaviour [55-58]. It is reported that the kinetics of asphaltene

93 precipitation near the onset of instability is very slow. A study by Jamialahmadi et al. (2009)

94 investigated the rate of asphaltene deposition from crude oil [59]. These researchers observed that

95 the oil velocity, surface and bulk temperature, and the concentration of the flocculated asphaltene

96 are the critical parameters with a dominant influence on the rate of asphaltene deposition. The

97 deposition rate has been observed to increase due to increases in flocculated asphaltene

98 concentration and surface temperature. Furthermore, as the oil velocity increases, the deposition

99 rate decreases. The same observations were reported by Soulgani et al. (2011) [60], Salimi et al.

100 (2013) [61], Arsalan et al. (2014) [54] and Haghshenasfard and Hooman (2015) [62]. Recent work

101 by Favero et al. (2016) studied the rate of asphaltene deposition as a function of fluid flow rate

102 [63]. These researchers concluded that the asphaltene deposition rate could increase with the 
103 concentration of unstable asphaltenes. The same experimental observation has been reported by 104 Ghahfarokhi et al. (2017) [64]. Taken together; these studies clearly show that a proper 105 understanding of the mechanism of asphaltene deposition is critical for the inhibition and/or 106 treatment of this issue in the oil industry.

107 To date, there have been no controlled studies which investigated the rate of the asphaltene 108 deposition in different EOR methods. The unsteady state analysis on the behavior of the asphaltene 109 particles in the presence of different gasses can generate a fresh insight into the prediction and 110 controlling asphaltene deposition phenomenon in the potential oil reservoirs. The present work 111 attempts to study the kinetics of asphaltene deposition rate at different operating pressures under 112 various gas injection scenarios. A tentative analysis is presented to compare the deposition rate 113 under different gas injection conditions using a visual high-pressure experimental apparatus. The 114 advantage of the current study is the evaluation of the asphaltene deposition rate using a visual 115 investigation which lays the groundwork for future research into asphaltene deposition. On the 116 other hand, the limitation on the analysis of the visual observation was a challenge in this study

117 which has been appropriately addressed to prove the effectiveness of the proposed approach in the 118 experiments.

119 The first part of this paper will present the experimental apparatus and the procedure. Then, in the 120 results and discussion section two main issues will be addressed; the effects of the different gas 121 injection scenarios on the asphaltene deposition rate, and analysis on the effects of the gas injection 122 on the asphaltene flocculation to explain the possible reasons behind the results of the experimental 123 tests.

\section{2. Experiments}

\section{$125 \quad$ 2.1. Experimental Apparatus}

126 The high-pressure experimental apparatus was constructed and developed to visually investigate 127 the rate of asphaltene deposition (Fig. 2). The experimental apparatus consists of a high-pressure 128 cell with a rotating metal disc which was horizontally placed in the cell as can be seen in Fig. 3 $129[21-23,64]$. Nine different types of glass substrates placed on the rotating disc to investigate the 130 process of the asphaltene deposition on the rock surface and collect the deposited asphaltene 131 particles during the experimental tests. The substrate plates have been used in order to mimic the 
132 sandstone in the oil reservoirs. A microscope (KRÜSS, MBL2000) with a potential optical 133 resolution up to $480 \mathrm{X}$ was used on the top of the high-pressure cell to visualise the process of 134 asphaltene deposition. A charge-coupled device (CCD) camera (IDS, UI-1485LE-C5 HQ, 5.7 135 megapixels) was used on the microscope to capture the high-resolution pictures from the deposited 136 asphaltenes on the substrates. A magnetic device was installed in the cell in order to adjust each 137 substrate in front of the microscope. The dark solution is placed on the substrate in the gap between 138 the light source and the microscope. More details of the experimental apparatus are reported 139 elsewhere [21-23, 64-66].

140 Different mole percentages of gases $\left(\mathrm{N}_{2}, \mathrm{CO}_{2}\right.$ and $\left.\mathrm{CH}_{4}\right)$ were injected into the cell. The process 141 of asphaltene deposition was detected via a high-resolution microscope. Image processing 142 software was used to determine the amount of deposited asphaltene and its size distribution under 143 different conditions [21-23, 64-66].

144 145

146 147 148 149 150 151

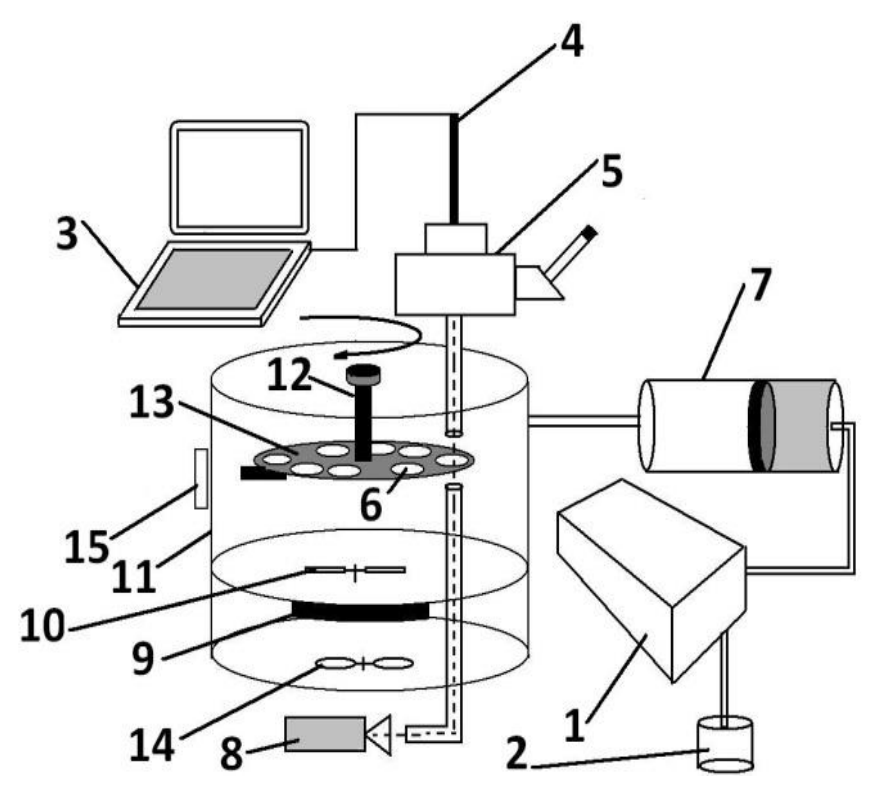

Fig. 2. Sketch of the high-pressure experimental apparatus [22]: (1) peristaltic pump, (2) distilled water reservoir, (3) computer, (4) CCD camera, (5) microscope, (6) sight glass, (7) pistoncylinder, (8) cold light source, (9) heater, (10) magnetic mixer, (11) high-pressure cell, (12) rotator, (13) metal disc, (14) fan, (15) magnetic device. 


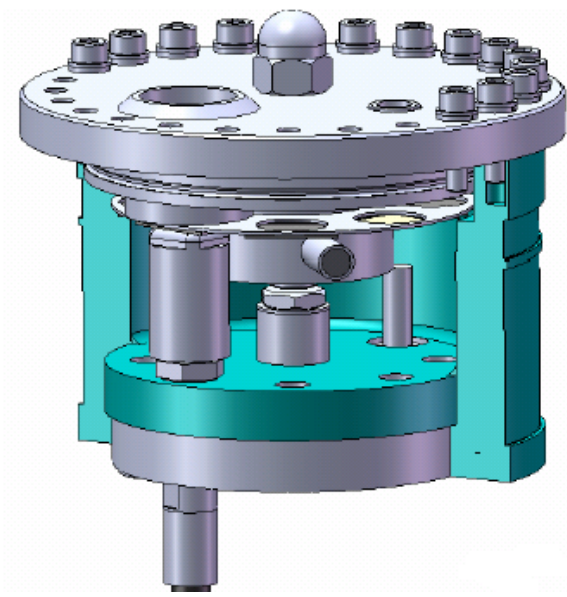

154 Fig 3. Schematic of the high-pressure cell to study the rate of the asphaltene deposition visually.

\subsection{Experimental Procedure}

156 A series of experiments were performed to study the asphaltene deposition rate using the following procedure: Firstly, asphaltene sample was extracted based on the method described by ASTM-D86

158 [67]. Synthetic oil was then prepared by mixing toluene $\left(\mathrm{C}_{7} \mathrm{H}_{8}\right)$ and normal heptane (n- $\left.\mathrm{C}_{7}\right)$ (Merck, 159 high-performance liquid chromatography grade). The mixture was mixed for 1 hour using a 160 magnetic stirrer and then used as synthetic oil. It is worth stating that the synthetic oil mixture is 161 stable at the atmospheric pressure and its bubble point is about 0.8 bar at $90{ }^{\circ} \mathrm{C}$. The saturate, 162 aromatic, resin and asphaltene analysis of the crude which asphaltene extracted from that is 163 reported in Table 1, and the synthetic oil composition is listed in Table 2. Furthermore, the results 164 of the elemental analysis on the asphaltene type used in this study reported by Sayyad Amin et al., 165 (2011) is presented in Table 3 [68]. They performed the elemental analysis using CHNSO analyzer 166 to measure the mass ratio of carbon $(\mathrm{C})$, hydrogen $(\mathrm{H})$, sulphur $(\mathrm{S})$, oxygen $(\mathrm{O})$, vanadium $(\mathrm{V})$ and 167 nickel (Ni).

168 The thermodynamic behaviour of reservoir fluid is the primary and essential step in reservoir 169 simulation, where a proper model should be validated and matched against the laboratory pressure, 170 volume and temperature (PVT) data. The reservoir fluid characterisation including the tuning of 171 the equation of state parameters using the same crude sample in this study was modelled and 172 validated to achieve a more accurate understanding of the reservoir fluid [69]. 
Table 1.

Saturate, aromatic, resin, and asphaltene analysis of the field sample [23].

175

176

177

178

179

180

181

182

183

184

185

186

187 (at constant temperature).

188 3- The solution was allowed to deposit asphaltene particles on the substrates. Images were taken 189 from the glass surfaces through the microscope at equal time steps to measure the amount of 190 deposited asphaltene. After approximately 2 hours, no more deposition was observed on the 191 horizontal glass surfaces indicating that the equilibrium had been reached. It, therefore, was the 192 time to proceed to the next step.

193 4- The pressure was decreased to 100 bar at constant temperature of $90^{\circ} \mathrm{C}$. Then the solution was 194 again stirred to remove all of the deposited asphaltene particles from the glass surfaces. 195 Accordingly, the asphaltene deposited on the glass plates was viewed, and images were captured 196 at the new pressure as well.

197 5- Previous step (4) was repeated at 60 and 30 bar pressures.

198 6- The amount of asphaltene deposited at each pressure and time step was estimated using the 199 image processing software to evaluate the rate of deposition. The high-resolution images were 
200 captured by the microscope and then analysed to evaluate the deposited asphaltene particles 201 diameter at high pressure and temperature (real thermodynamic condition).

202 The deposited asphaltene particle diameter was estimated by SigmaScan Pro $5^{\mathrm{TM}}$ software based 203 on the area and darkness of each particle. At the first step, the software should be calibrated and 204 then it could measure the size and diameter of each particle. More details of the calibration method 205 have been described in the Supplementary Material. After the calibration, the accuracy was 206 tested by weighing the deposited particles on the sample glass at the atmospheric pressure. The 207 calibration process was repeated for the next time step if it was needed. The mass of deposited 208 asphaltene on the substrate was estimated using the density of extracted asphaltene. Having the 209 total amount of dissolved asphaltene in the space between the glass surface and cell head (volume $210=$ glass surface area $\times$ height), the weight fraction of deposited asphaltene was calculated. In order 211 to avoid any localized errors, the average amount of deposited asphaltene on nine substrates was 212 reported as the final result. It should be noted that each test session was repeated three times to 213 check the accuracy.

214 As a side note, based on the microscope imaging, it is possible to focus on the fluid and the solid 215 surface, and therefore the lens was adjusted and focused solely on the glass substrate surface. Thus 216 all dark particles on the images are flocculated asphaltene deposited on the glass surface, not the 217 asphaltene presence in bulk. On the other hand, it is impossible to capture and record the whole 218 asphaltene particles in the bulk of fluid by a microscope because of their different position to the 219 microscope lens. In summary, all the dark particles are the deposited asphaltene on the glass 220 surface.

221 To evaluate the effects of $\mathrm{N}_{2}, \mathrm{CO}_{2}$ and $\mathrm{CH}_{4}$ on the rate of the asphaltene deposition, $10 \mathrm{~mol} \%$ of 222 the prepared gas was injected into the synthetic oil by a piston-cylinder setup. At the first step, the 223 desired amount of gas was injected into the cylinder, then using an HPLC pump the gas was 224 injected into the high-pressure cell. Steps 1-6 were repeated for $\mathrm{CO}_{2}, \mathrm{CH}_{4}$, and $\mathrm{N}_{2}$ injection 225 scenarios.

226 It is worth mentioning that the minimum miscibility pressure (MMP) was checked theoretically 227 and experimentally for different gas injection scenarios in this study. According to the results, 228 MMP for the mixture of oil and different gases used in this study was less than 30 bar at $90^{\circ} \mathrm{C}$. 229 Moreover, in the present research, the amount of deposited asphaltene was investigated at 230 pressures (30, 60, 100 and 140 bar) higher than MMP. Therefore, all the experiments were 
231 conducted under a single-phase condition. In this regard, it could be concluded that whole injected 232 gas can be considered as the solution gas.

233 The findings of this study may be somewhat limited by; 1) It was impossible to investigate the rate 234 of asphaltene deposition at pressures less than 30 bar because of missing the miscibility condition,

235 2) The glass surface was used instead of a porous medium to visualize the deposition process.

\section{3. Results and Discussion}

\section{3.1. Effects of different gas injection scenarios on asphaltene deposition rate}

238 The images captured at equal time intervals show that the asphaltene particles deposit on the glass 239 surface over time. Image analysis revealed that after approximately 2 hours, the asphaltene 240 deposition process reaches a steady-state condition, meaning that no additional asphaltene deposits 241 are observed on the glass surface after this point.

242 Fig. 4 clearly shows the impact of pressure increment on the amount of deposited asphaltene. It is

243 worth stressing that dark areas in the images represent flocculated asphaltene deposited on the

244 glass substrates. As can be seen in Fig. 4, pressure increment leads to a higher amount of asphaltene 245 deposition.

246 Fig. 5 represents the asphaltene deposition at different times for the case without gas injection. The

247 images indicate that the amount of deposited asphaltene increases over time until it reaches the 248 steady state condition. Experimental observations and processing of the images captured after 2 249 hours revealed that no additional deposition occurs after approximately 2 hours. The images show 250 that as the pressure increases from 30 to 140 bar, the amount of deposited asphaltene increases too. 251 Increasing pressure seems to affect the solubility of asphaltene molecules in solution. For further 252 clarification, the supplementary video shows the movement and asphaltene deposition on the glass 253 substrate at 30 bar and $90^{\circ} \mathrm{C}$. 


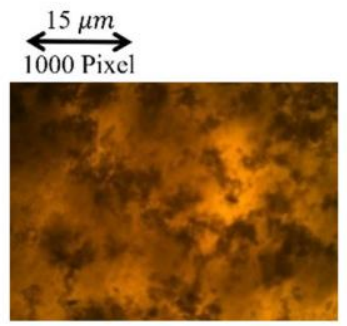

256

257

258

259

260

261

262

263

264

265

266

267

268

269

270

271

272 273

274

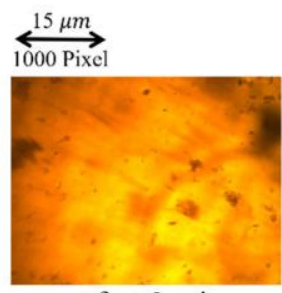

after $0 \mathrm{~min}$

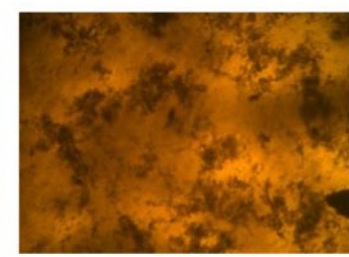

100 bar

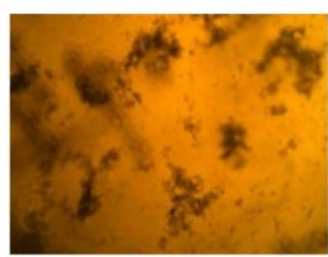

60 bar

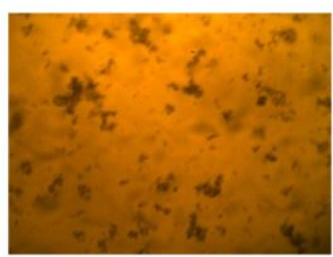

30 bar

Fig. 4. Effect of pressure on the amount of asphaltene deposition, after 2 hours at $90^{\circ} \mathrm{C}$.

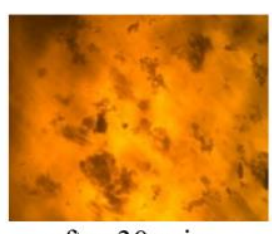

after $30 \mathrm{~min}$

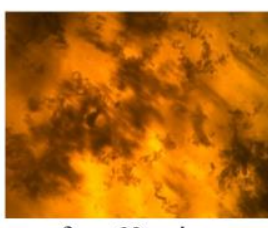

after $60 \mathrm{~min}$

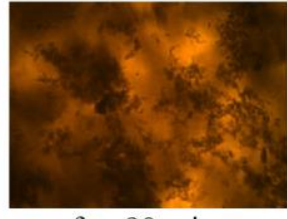

after $90 \mathrm{~min}$

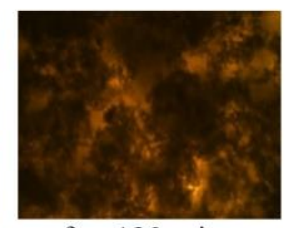

after $120 \mathrm{~min}$

Fig. 5. Asphaltene deposition at different times, without gas injection, 100 bar and $90^{\circ} \mathrm{C}$.

The second part of the current study aims to consider the effect of different gas injection scenarios on the asphaltene deposition process by injecting $10 \mathrm{~mol} \%$ of $\mathrm{CO}_{2}, \mathrm{CH}_{4}$ and $\mathrm{N}_{2}$ into the highpressure cell using a cylinder-piston setup. Firstly, the specified volume of gas was injected into the cylinder, then using an HPLC pump the gas was injected into the high-pressure cell gradually. The results presented in Figs. 6-8 show a significant difference between the $\mathrm{CO}_{2}$ injection and without gas injection scenarios. Comparing Figs. 5 and 8 clearly indicate that the injection of $\mathrm{CO}_{2}$ into the synthetic oil solution results in a higher deposition rate that is up to 1.5 times faster than that observed for the case study without gas injection at 140 bar pressure. Due to the fact that both asphaltene and $\mathrm{CO}_{2}$ have polar molecules may lead to a higher interaction coefficient between them, finally resulting in higher asphaltene deposition and consequently a faster deposition rate. 


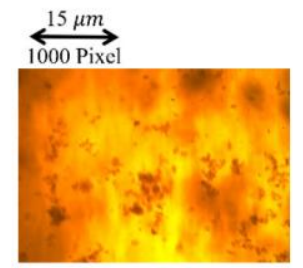

after $0 \mathrm{~min}$

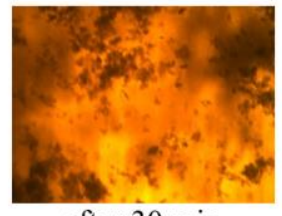

after $30 \mathrm{~min}$

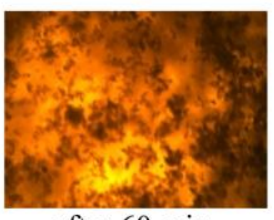

after $60 \mathrm{~min}$

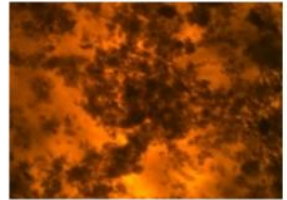

after $90 \mathrm{~min}$

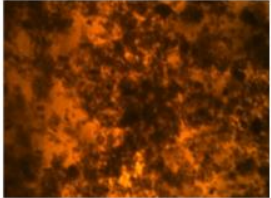

after $120 \mathrm{~min}$

Fig. 6. Asphaltene deposition at various times, $10 \mathrm{~mol} \% \mathrm{~N}_{2}$ injection, 100 bar and $90^{\circ} \mathrm{C}$.

278

279

280

281

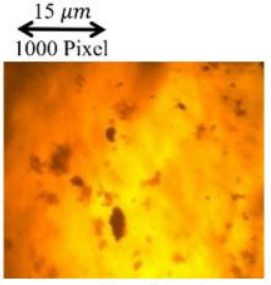

after $0 \mathrm{~min}$

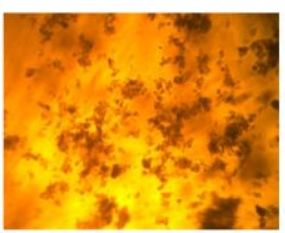

after $30 \mathrm{~min}$

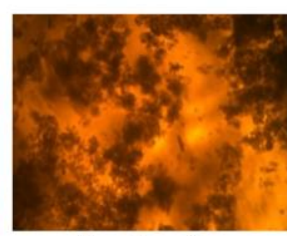

after $60 \mathrm{~min}$

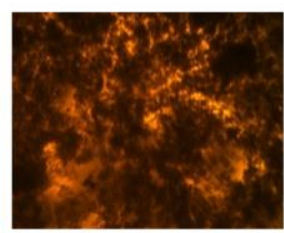

after $90 \mathrm{~min}$

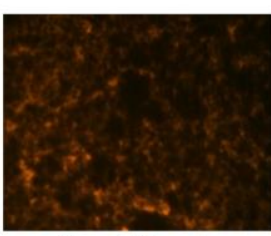

after $120 \mathrm{~min}$

Fig. 7. Asphaltene deposition at different times, $10 \mathrm{~mol} \% \mathrm{CH}_{4}$ injection, 100 bar and $90^{\circ} \mathrm{C}$.

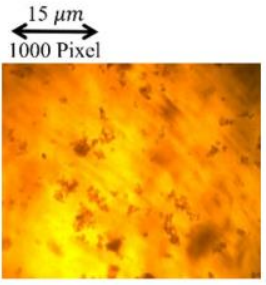

after $0 \mathrm{~min}$

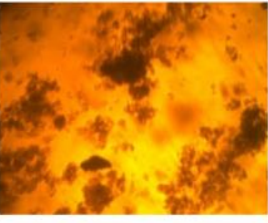

after $30 \mathrm{~min}$

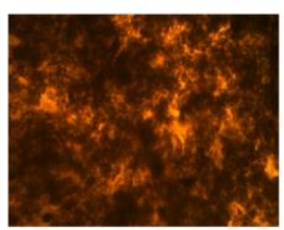

after $60 \mathrm{~min}$

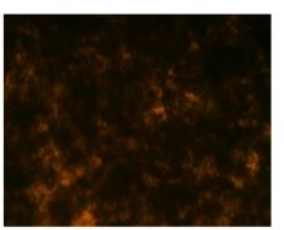

after $90 \mathrm{~min}$

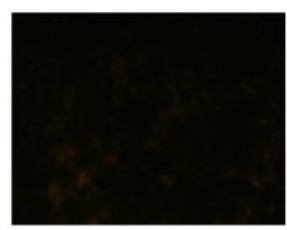

after $120 \mathrm{~min}$

Fig. 8. Asphaltene deposition at different times during $10 \mathrm{~mol} \% \mathrm{CO}_{2}$ injection at 100 bar and $90^{\circ} \mathrm{C}$.

Comparing the results presented in Figs. 7 and 8 reveals that the $\mathrm{CO}_{2}$ injection scenario results in a higher amount of asphaltene deposition comparing the results with $\mathrm{CH}_{4}$ injection scenario. In order to make a better comparison, Fig. 9 shows the effect of different gas injection scenarios on the amount of asphaltene deposition after $120 \mathrm{~min}$, at $100 \mathrm{bar}$ and $90^{\circ} \mathrm{C}$. It is apparent from the figure that $\mathrm{N}_{2}$ injection has not a significant impact on the deposition process in contrast to the scenario with injected $\mathrm{CO}_{2}$ and $\mathrm{CH}_{4}$. Besides, Fig. 10 compares the effect of different gas injection scenarios on the amount of deposited asphaltene at various pressures which have been evaluated

294 gas injections on the amount of the deposited asphaltene. The quantitative data on deposited 
295 asphaltene versus time at different pressures and different gas injection scenarios are shown in 296 Tables 4-7 for all scenarios.

297

298

299

300

301

302

303

304

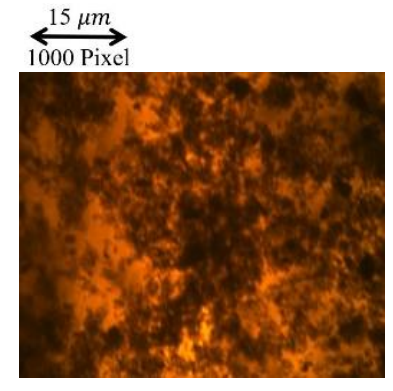

$\mathrm{N}_{2}$

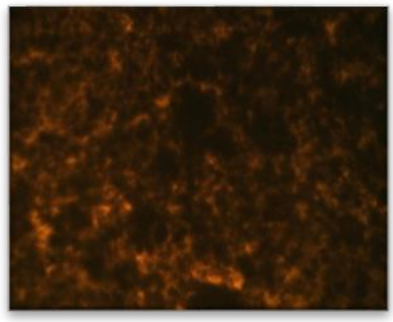

$\mathrm{CH}_{4}$

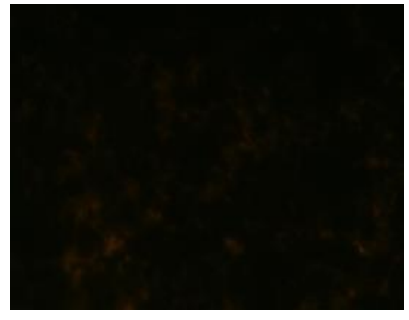

$\mathrm{CO}_{2}$

Fig. 9. Effects of different gases injection on the asphaltene deposition, after $120 \mathrm{~min}$, at 100 bar and $90^{\circ} \mathrm{C}$.

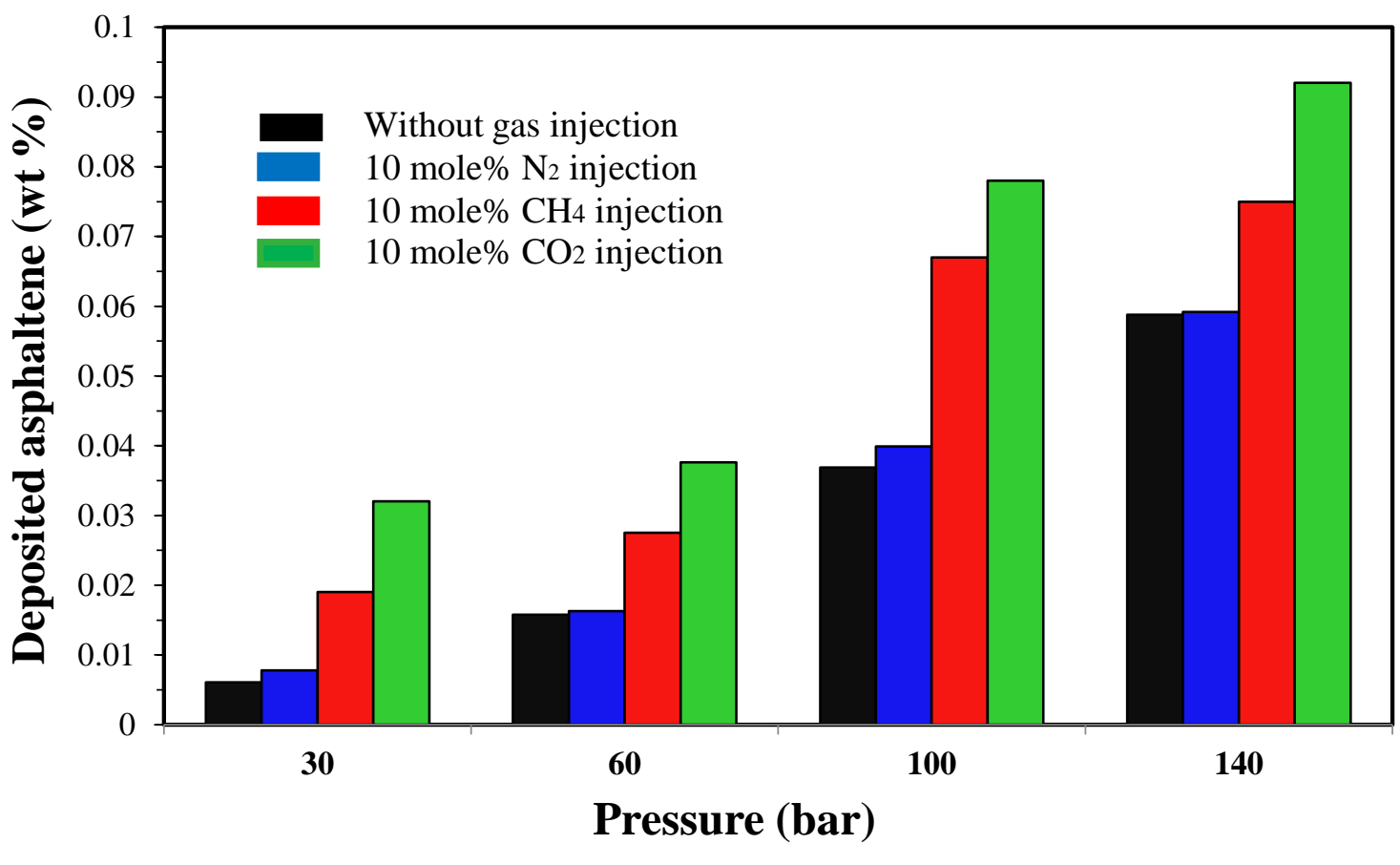

Fig. 10. A comparison of Asphaltene deposition during different gas injection scenarios after 120 min at different pressures and $90^{\circ} \mathrm{C}$. 
311 Table 4.

312 Asphaltene deposition versus time - without gas injection at $90^{\circ} \mathrm{C}$.

\begin{tabular}{|c|c|c|c|c|c|c|c|c|c|c|}
\hline $\begin{array}{l}\text { Time } \\
(\mathrm{min})\end{array}$ & 0 & 30 & 60 & 90 & 120 & 0 & 30 & 60 & 90 & 120 \\
\hline $\begin{array}{c}\text { Pressure } \\
\text { (bar) }\end{array}$ & \multicolumn{5}{|c|}{ Asphaltene deposited (wt \%) } & \multicolumn{5}{|c|}{ Standard deviation } \\
\hline 30 & 0 & 0.00100 & 0.00280 & 0.00430 & 0.00610 & 0 & 0.00015 & 0.00040 & 0.00035 & 0.00065 \\
\hline 60 & 0 & 0.00300 & 0.00800 & 0.01100 & 0.01580 & 0 & 0.00030 & 0.00020 & 0.00250 & 0.00260 \\
\hline 100 & 0 & 0.00550 & 0.01100 & 0.02690 & 0.03690 & 0 & 0.00095 & 0.00100 & 0.00130 & 0.00180 \\
\hline 140 & 0 & 0.01000 & 0.02900 & 0.04300 & 0.05880 & 0 & 0.00060 & 0.00350 & 0.00175 & 0.00260 \\
\hline
\end{tabular}

Table 5 .

316 Asphaltene deposition versus time $-10 \mathrm{~mol} \% \mathrm{~N}_{2}$ at $90^{\circ} \mathrm{C}$.

\begin{tabular}{|c|c|c|c|c|c|c|c|c|c|c|}
\hline $\begin{array}{l}\text { Time } \\
(\mathrm{min})\end{array}$ & 0 & 30 & 60 & 90 & 120 & 0 & 30 & 60 & 90 & 120 \\
\hline $\begin{array}{c}\text { Pressure } \\
\text { (bar) }\end{array}$ & & \multicolumn{4}{|c|}{ Asphaltene deposited (wt \%) } & \multicolumn{5}{|c|}{ Standard deviation } \\
\hline 30 & 0 & 0.00120 & 0.00320 & 0.00540 & 0.00780 & 0 & 0.00025 & 0.00045 & 0.00085 & 0.00050 \\
\hline 60 & 0 & 0.00330 & 0.00890 & 0.01180 & 0.01630 & 0 & 0.00030 & 0.00035 & 0.00105 & 0.00100 \\
\hline 100 & 0 & 0.00590 & 0.01280 & 0.02880 & 0.03990 & 0 & 0.00040 & 0.00135 & 0.00110 & 0.00080 \\
\hline 140 & 0 & 0.01100 & 0.02940 & 0.04380 & 0.05920 & 0 & 0.00215 & 0.00195 & 0.00120 & 0.00135 \\
\hline
\end{tabular}

317

318

319

320

321

322

323

324

325

326

327

328

329

Table 6.

Asphaltene deposition versus time $-10 \mathrm{~mol}^{\%} \mathrm{CH}_{4}$ at $90^{\circ} \mathrm{C}$.

\begin{tabular}{cccccc|ccccc}
\hline $\begin{array}{c}\text { Time } \\
\text { (min) }\end{array}$ & 0 & 30 & 60 & 90 & 120 & 0 & 30 & 60 & 90 & 120 \\
\hline $\begin{array}{c}\text { Pressure } \\
\text { (bar) }\end{array}$ & \multicolumn{1}{c|}{ Asphaltene deposited (wt \%) } & \multicolumn{5}{c}{ Standard deviation } \\
\hline 30 & 0 & 0.00450 & 0.00830 & 0.01300 & 0.01940 & 0 & 0.00020 & 0.00055 & 0.00105 & 0.00080 \\
60 & 0 & 0.00730 & 0.01470 & 0.02100 & 0.02750 & 0 & 0.00025 & 0.00120 & 0.00175 & 0.00135 \\
100 & 0 & 0.00930 & 0.03010 & 0.05200 & 0.06700 & 0 & 0.00060 & 0.00215 & 0.00215 & 0.00300 \\
140 & 0 & 0.01680 & 0.04900 & 0.06700 & 0.07500 & 0 & 0.00115 & 0.00230 & 0.00250 & 0.00175 \\
\hline
\end{tabular}


Table 7.

331 Asphaltene deposition versus time $-10 \mathrm{~mol} \% \mathrm{CO}_{2}$ at $90^{\circ} \mathrm{C}$.

\begin{tabular}{ccccc|cccccc}
\hline $\begin{array}{c}\text { Time } \\
(\mathrm{min})\end{array}$ & 0 & 30 & 60 & 90 & 120 & 0 & 30 & 60 & 90 & 120 \\
\hline $\begin{array}{c}\text { Pressure } \\
\text { (bar) }\end{array}$ & \multicolumn{1}{c|}{ Asphaltene deposited (wt \%) } & \multicolumn{5}{c}{ Standard deviation } \\
\hline 30 & 0 & 0.00510 & 0.01710 & 0.02140 & 0.03200 & 0 & 0.00040 & 0.00035 & 0.00035 & 0.00055 \\
60 & 0 & 0.00870 & 0.01950 & 0.02890 & 0.03760 & 0 & 0.00030 & 0.00075 & 0.00115 & 0.00095 \\
100 & 0 & 0.01540 & 0.03660 & 0.06160 & 0.07800 & 0 & 0.00105 & 0.00255 & 0.00110 & 0.00250 \\
140 & 0 & 0.02140 & 0.05790 & 0.07120 & 0.09200 & 0 & 0.00155 & 0.00205 & 0.00131 & 0.00320 \\
\hline
\end{tabular}

333 These results may be explained by the fact that the interaction coefficient between $\mathrm{N}_{2}$ and

334 asphaltene molecules is less than that between $\mathrm{CO}_{2} / \mathrm{CH}_{4}$ and asphaltene molecules. Previous

335 research findings on the thermodynamic modelling of asphaltene deposition have confirmed that

336 the interaction coefficient between gas and asphaltene molecules is the critical parameter used to

337 evaluate the amount of asphaltene deposition, where the higher interaction coefficient leads to

338 more asphaltene deposition [22, 70]. Based on the solid model, the interaction coefficient is

339 determined by the following equation [70]:

$340 \quad d_{i k}=1-\left(\frac{2 \cdot v_{i c}^{\frac{1}{6}} \cdot v_{c k}^{\frac{1}{6}}}{v_{c i}^{\frac{1}{3}}+v_{c k}^{\frac{1}{3}}}\right)^{e} \quad \quad \mathrm{i}=2, \ldots, 12 ; \mathrm{k}=2, \ldots, 12$

341 where $d_{i k}$ is the interaction coefficient between components $i$ and $k$, and $v_{c i}$ and $v_{c k}$ are the critical

342 volumes of components $i$ and $k$, respectively. The interaction coefficients between $\mathrm{N}_{2}, \mathrm{CO}_{2}, \mathrm{CH}_{4}$

343 and asphaltene molecules at different mole percent gas injection using the CMG simulator

344 (WinProp fluid property characterization tool) have been compared in Table 8. The higher

345 interaction coefficients between asphaltene molecules and $\mathrm{CO}_{2}$ and $\mathrm{CH}_{4}$ confirm our experimental

346 results regarding the higher amount of the asphaltene deposition in these two cases.

Table 8.

The analysis of the interaction coefficient between different gasses and asphaltene molecule [22, 23].

\begin{tabular}{lllll}
\hline & \multicolumn{4}{c}{ Gas injection (mol\%) } \\
\hline & 0.05 & 0.10 & 0.15 & 0.20 \\
\cline { 2 - 5 } $\mathrm{N}_{2}$ /asphaltene interaction coefficient & 0.03 & 0.04 & 0.08 & 0.13 \\
$\mathrm{CH}_{4} /$ asphaltene interaction coefficient & 0.10 & 0.12 & 0.15 & 0.22 \\
$\mathrm{CO}_{2} /$ asphaltene interaction coefficient & 0.16 & 0.20 & 0.24 & 0.35 \\
\hline
\end{tabular}


349 To have a better assessment, Figs. 11-14 illustrate asphaltene deposition over time at different 350 operating pressures for different gas injection scenarios. The results indicate that the deposition 351 rate increases notably during $\mathrm{CO}_{2}$ and $\mathrm{CH}_{4}$ injection. Also, it could be concluded that $\mathrm{CH}_{4}$ affects 352 the asphaltene deposition rate more than $\mathrm{N}_{2}$ and less than $\mathrm{CO}_{2}$.

353 It can be seen that the rate of deposition at 140 bar pressure is 10 times faster than at 30 bar 354 pressure. It should be noted that to ensure the accuracy of the results, all of the experimental tests 355 were repeated three times.

356

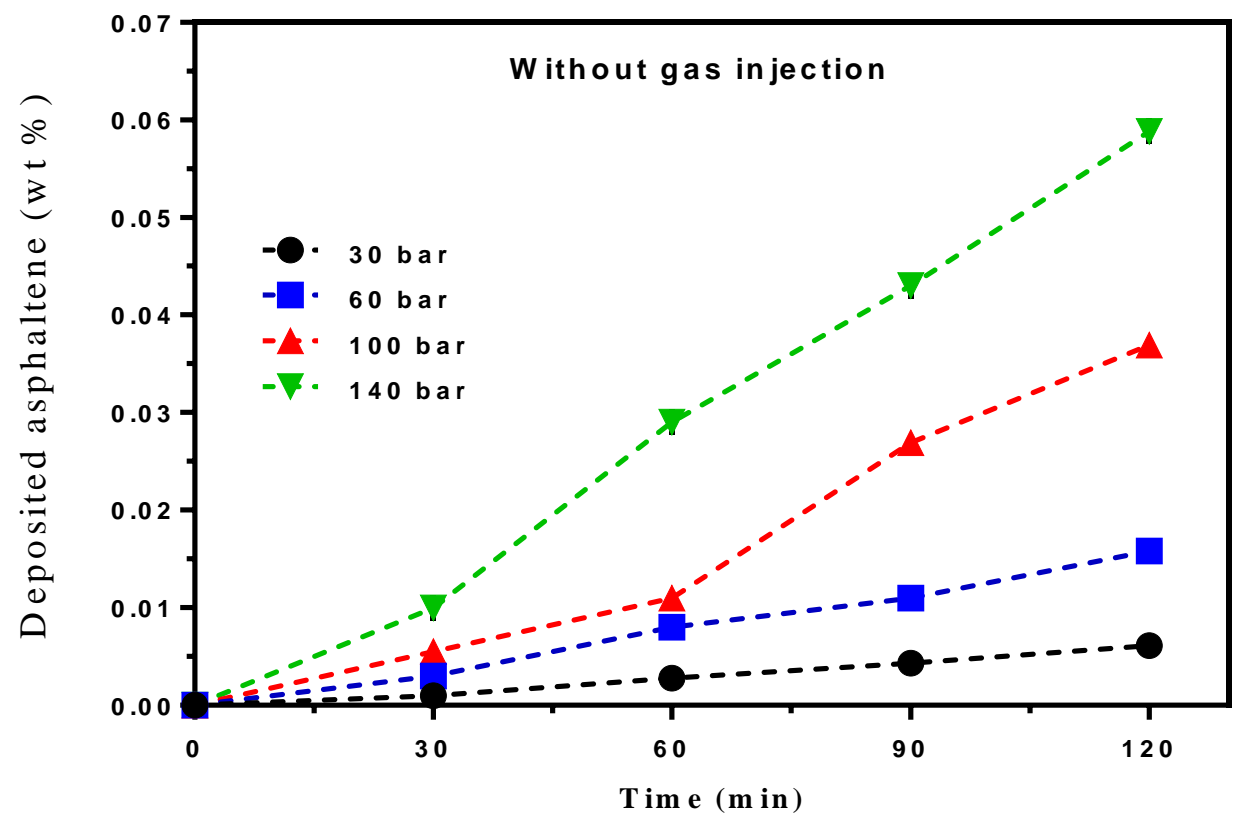

358 Fig. 11. Asphaltene deposition rate without gas injection at 30, 60, 100 and 140 bar pressures and $35990^{\circ} \mathrm{C}$. 


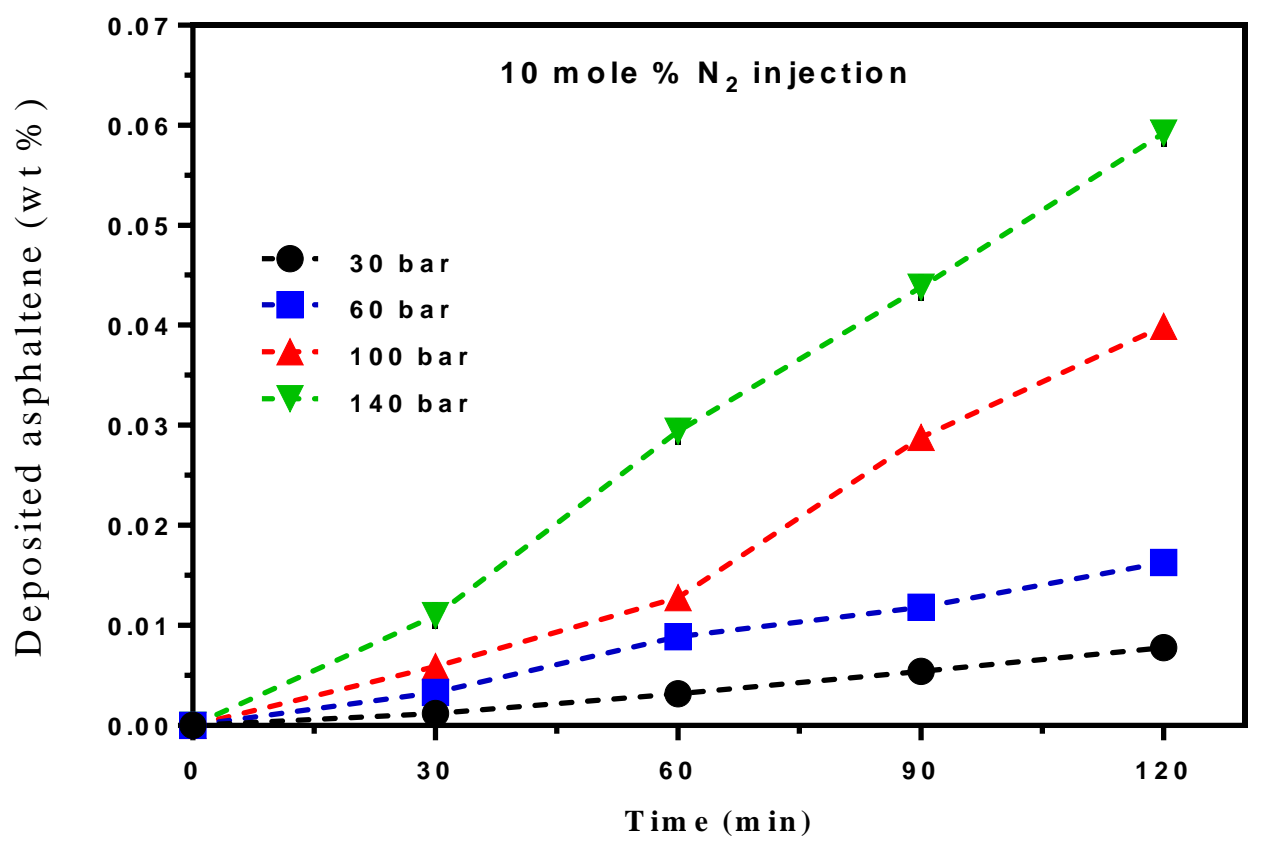

361 Fig. 12. Asphaltene deposition rate during $10 \mathrm{~mol} \% \mathrm{~N}_{2}$ injection at 30, 60, 100 and 140 bar 362 pressures and $90^{\circ} \mathrm{C}$.

363

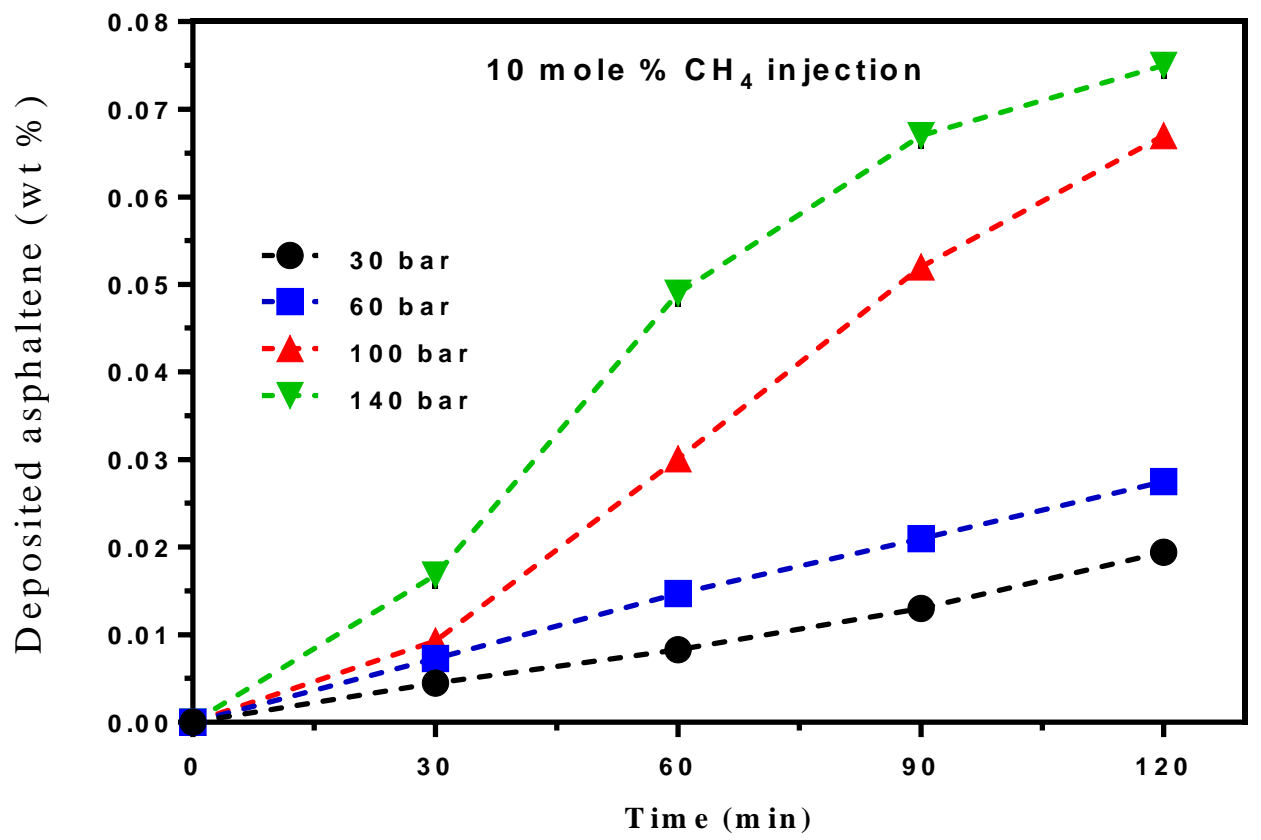

Fig. 13. Asphaltene deposition rate during $10 \mathrm{~mol}_{\mathrm{C}} \mathrm{CH}_{4}$ injection at 30, 60, 100 and 140 bar pressures and $90^{\circ} \mathrm{C}$. 


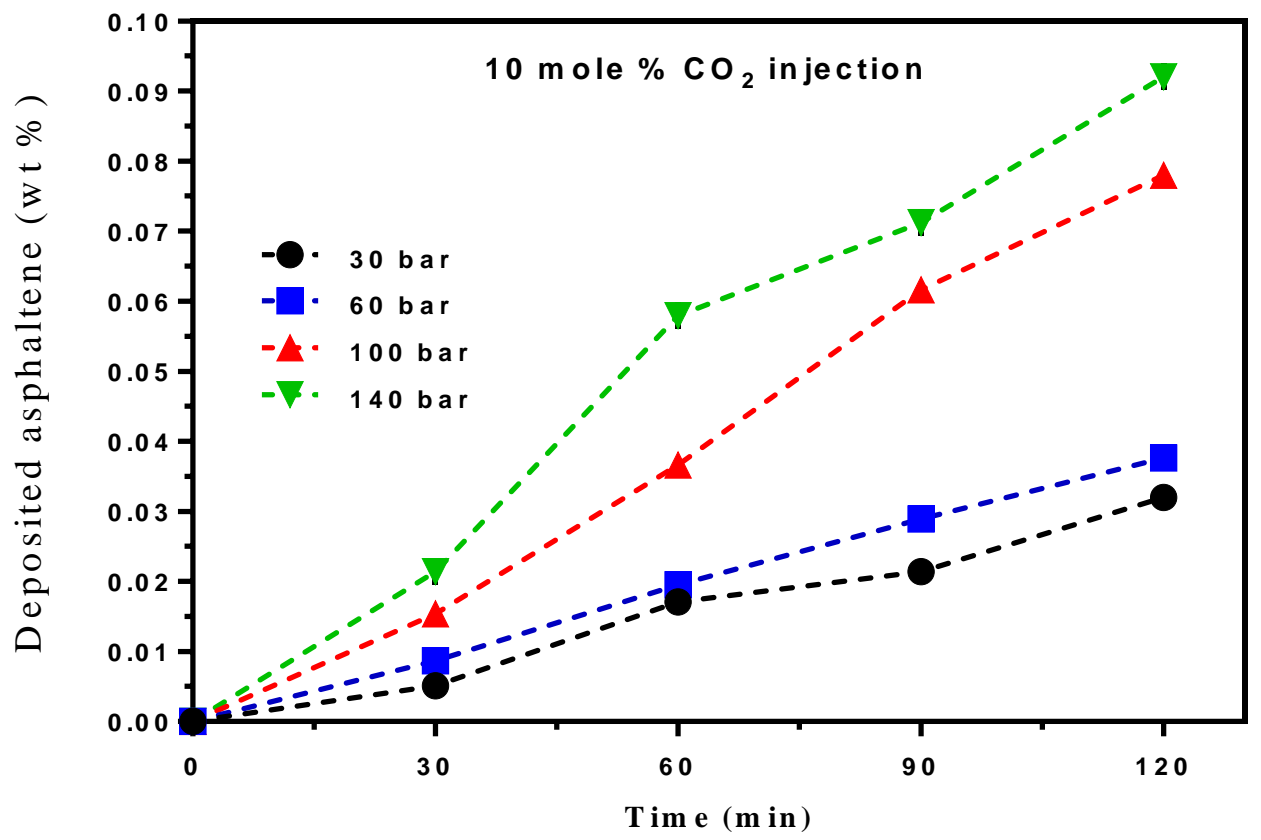

369

370

371

372

\section{3}

374

375

376

377

378

379

380

381

382

383

384

385

386

Fig. 14. Asphaltene deposition rate during $10 \mathrm{~mol} \% \mathrm{CO}_{2}$ injection at 30, 60, 100 and $140 \mathrm{bar}$ pressures and $90^{\circ} \mathrm{C}$.

\subsection{Effects of gas injection on the asphaltene flocculation}

Experimental observations showed that gas injection affected asphaltene flocculation and caused asphaltene particles to make bigger flocs [71-73]. Due to the fact that deposition of asphaltene flocs leads to wettability reduction in the porous media of reservoir rocks, this phenomenon could be damaging in gas injection-EOR methods.

In a further analysis in this study, the asphaltene fluctuation behaviour in the presence of the different gas injection scenarios has been examined. Figs. 15-18 show asphaltene flocculation during different gas injection scenarios. To make a better comparison, Fig. 19 shows the effect of gas injection on the size of flocculated asphaltene particles measured by SigmaScan Pro $5^{\mathrm{TM}}$ software. It is apparent from Figs. $15-19$ that $\mathrm{CH}_{4}$ and $\mathrm{CO}_{2}$ injection leads to the formation of bigger asphaltene flocs compared the results with $\mathrm{N}_{2}$ injection. However, $\mathrm{N}_{2}$ injection does not affect asphaltene flocculation significantly. A comparison of results reveals that $\mathrm{CO}_{2}$ injection influences asphaltene flocculation more than $\mathrm{CH}_{4}$. 


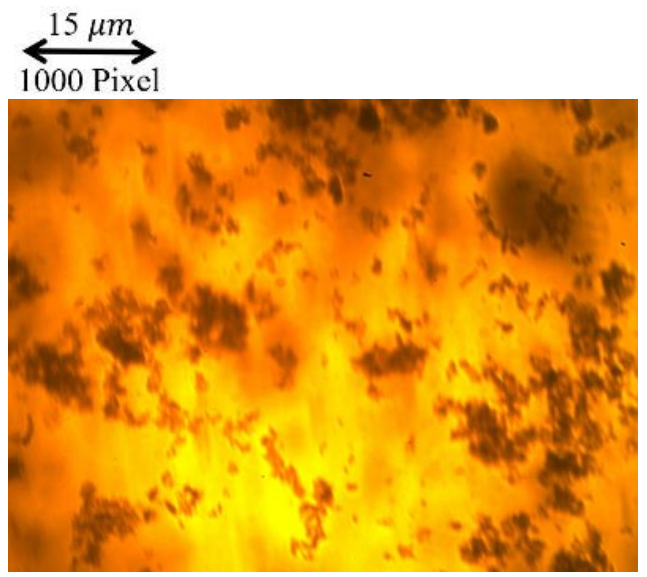

Fig. 15. Asphaltene flocculation without gas injection at 140 bar and $90^{\circ} \mathrm{C}$. 

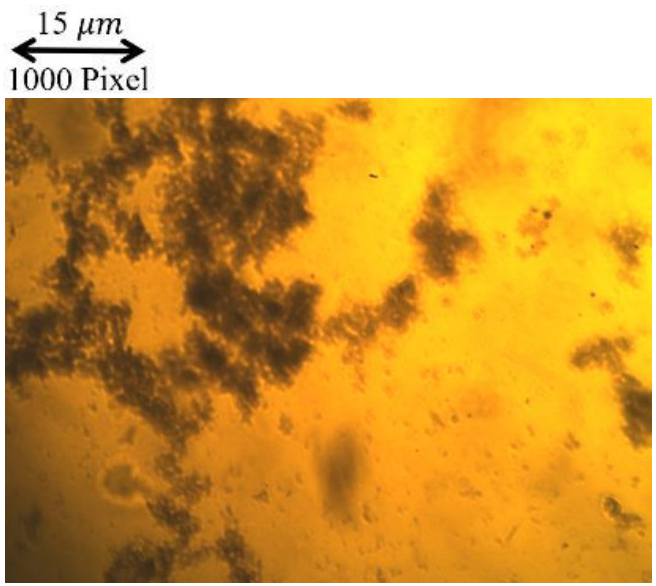

398

399

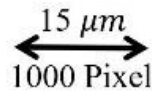

Fig. 17. Asphaltene flocculation with 10 mole $\% \mathrm{CH}_{4}$ injection at 140 bar and $90^{\circ} \mathrm{C}$.

Fig. 18. Asphaltene flocculation with 10 mole $\% \mathrm{CO}_{2}$ injection at 140 bar and $90^{\circ} \mathrm{C}$.

402

403

404 


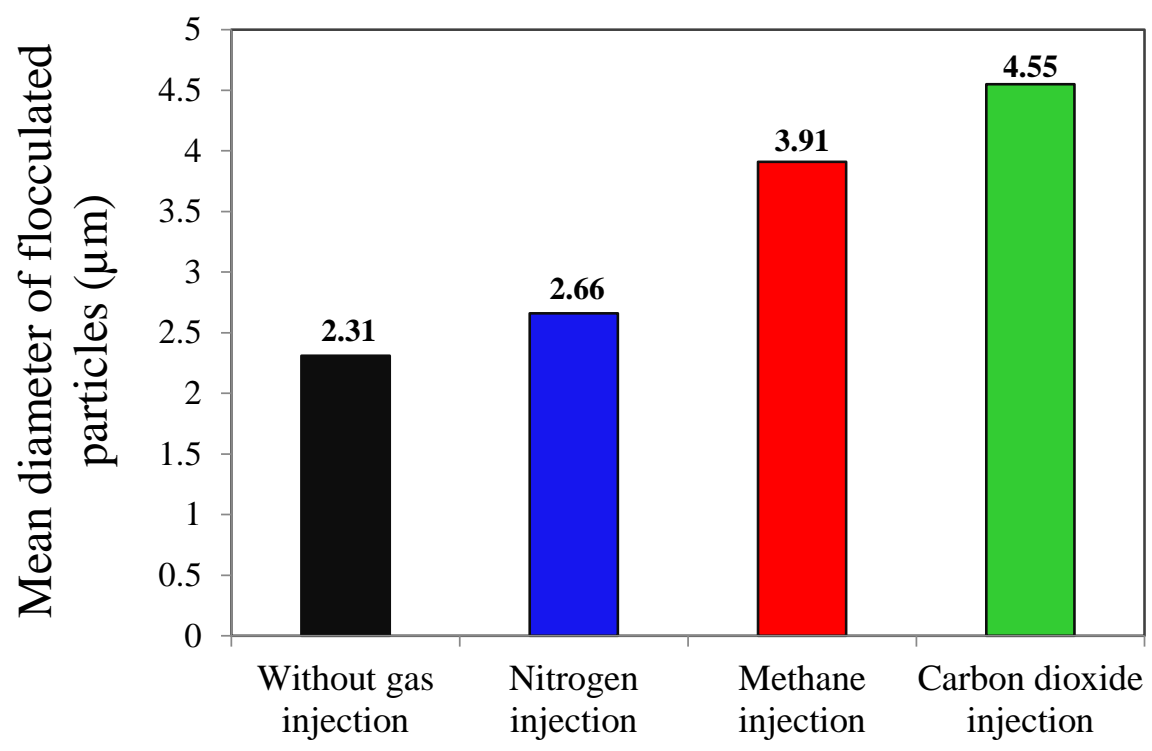

405

406 Fig. 19. Effects of different gas injection scenarios on asphaltene flocculation at 140 bar and $40790^{\circ} \mathrm{C}$.

\section{4. Conclusions}

409 Asphaltene deposition during EOR processes is of particular concern in the oil industry. A proper 410 understanding of the asphaltene deposition mechanism would help researchers to develop methods 411 for asphaltene inhibition or treatment. The present study was designed to determine the effect of 412 different gas injection processes as EOR methods on the asphaltene deposition rate at different 413 pressure conditions. A series of experiments were conducted in a high-pressure cell to investigate 414 the deposition rate under various gas injection scenarios. The following major findings are 415 identified in the current paper:

416 - According to the results, when there is no gas injection, the rate of asphaltene deposition 417 increases as the pressure increases. For example, the rate of deposition at 140 bar is 11.7 418 times greater than that at 30 bar pressure.

419 - The results obtained with different gas injection scenarios revealed that $\mathrm{CO}_{2}$ and $\mathrm{CH}_{4}$ affect 420 the rate of deposition and lead to a significant increase in the amount of deposition. For 421 instance, at 140 bar and $90^{\circ} \mathrm{C}$, the amount of deposited asphaltene without gas injection is $0.05880 \mathrm{wt} \%$, increasing to 0.07500 and $0.09200 \mathrm{wt} \%$ for $10 \mathrm{~mol} \%$ injection of $\mathrm{CH}_{4}$ and 
$\mathrm{CO}_{2}$, respectively. Taken together, the results suggest that carbon dioxide results in more deposition than methane and $\mathrm{N}_{2}$ at the same gas injection concentration.

- Based on the experimental results, $\mathrm{N}_{2}$ injection had a minimum effect on the rate of deposition compared with $\mathrm{CH}_{4}$ and $\mathrm{CO}_{2}$ injection scenarios.

- The effect of gas injection on asphaltene flocculation was investigated. It was revealed that gas injection affects the flocculation process. The results showed that $\mathrm{CO}_{2}$ and $\mathrm{CH}_{4}$ injection leads to the formation of bigger asphaltene flocs in comparison with $\mathrm{N}_{2}$. However, $\mathrm{N}_{2}$ injection did not affect asphaltene flocculation significantly. The results of this study provide valuable insights into the mechanism asphaltene deposition rate due to the different gas injection scenarios.

\section{References}

[1] D.L. Mitchell, J.G. Speight, The solubility of asphaltenes in hydrocarbon solvents, Fuel, 52 (1973) 149-152.

[2] J.G. Speight, The Chemistry and Technology of Petroleum, Fifth ed., Taylor \& Francis, 2014. [3] H. Groenzin, O.C. Mullins, Molecular size and structure of asphaltenes from various sources, Energy \& Fuels, 14 (2000) 677-684. [4] A.R. Hortal, B. Martínez-Haya, M.D. Lobato, J.M. Pedrosa, S. Lago, On the determination of molecular weight distributions of asphaltenes and their aggregates in laser desorption ionization experiments, Journal of Mass Spectrometry, 41 (2006) 960-968.

[5] G.C. Klein, S. Kim, R.P. Rodgers, A.G. Marshall, A. Yen, S. Asomaning, Mass spectral analysis of asphaltenes. I. Compositional differences between pressure-drop and solvent-drop asphaltenes determined by electrospray ionization fourier transform ion cyclotron resonance mass spectrometry, Energy \& Fuels, 20 (2006) 1965-1972.

[6] G.A. Mansoori, D. Vazquez, M. Shariaty-Niassar, Polydispersity of heavy organics in crude oils and their role in oil well fouling, Journal of Petroleum Science and Engineering, 58 (2007) 375-390.

[7] G.A. Mansoori, Modeling of asphaltene and other heavy organic depositions, Journal of Petroleum Science and Engineering, 17 (1997) 101-111.

459 [11] S.P. Tan, X. Qiu, M. Dejam, H. Adidharma, Critical Point of Fluid Confined in Nanopores: 460 Experimental Detection and Measurement, The Journal of Physical Chemistry C, 123 (2019) 98244619830. 
462

463

464

465

466

467

468

469

470

471

472

473

474

475

476

477

478

479

480

481

482

483

484

485

486

487

488

489

490

491

492

493

494

495

496

497

498

499

500

501

502

503

504

505

506

507

[12] X. Qiu, S.P. Tan, M. Dejam, H. Adidharma, Simple and accurate isochoric differential scanning calorimetry measurements: phase transitions for pure fluids and mixtures in nanopores, Physical Chemistry Chemical Physics, 21 (2019) 224-231.

[13] X. Qiu, S.P. Tan, M. Dejam, H. Adidharma, Novel isochoric measurement of the onset of vapor-liquid phase transition using differential scanning calorimetry, Physical Chemistry Chemical Physics, 20 (2018) 26241-26248.

[14] J.H. Pacheco-Sanchez, G.A. Mansoori, Prediction of the phase behavior of asphaltene micelle/aromatic hydrocarbon systems, Petroleum Science and Technology, 16 (1998) 377-394.

[15] W. Chaisoontornyotin, A.W. Bingham, M.P. Hoepfner, Reversibility of Asphaltene Precipitation Using Temperature-Induced Aggregation, Energy \& Fuels, 31 (2017) 3392-3398.

[16] M.P. Hoepfner, V. Limsakoune, V. Chuenmeechao, T. Maqbool, H.S. Fogler, A Fundamental Study of Asphaltene Deposition, Energy \& Fuels, 27 (2013) 725-735.

[17] S.J. Park, G.A. Mansoori, Aggregation and deposition of heavy organics in petroleum crudes, Energy Sources, 10 (1988) 109-125.

[18] K.J. Leontaritis, G.A. Mansoori, Asphaltene deposition: a survey of field experiences and research approaches, Journal of Petroleum Science and Engineering, 1 (1988) 229-239.

[19] F. Soorghali, A. Zolghadr, S. Ayatollahi, Effect of resins on asphaltene deposition and the changes of surface properties at different pressures: A microstructure study, Energy \& Fuels, 28 (2014) 2415-2421.

[20] S.I. Andersen, Effect of precipitation temperature on the composition of N-Heptane asphaltenes Part 2, Fuel Science and Technology International, 13 (1995) 579-604.

[21] P. Zanganeh, S. Ayatollahi, A. Alamdari, A. Zolghadr, H. Dashti, S. Kord, Asphaltene Deposition during $\mathrm{CO}_{2}$ Injection and Pressure Depletion: A Visual Study, Energy \& Fuels, 26 (2012) 1412-1419.

[22] P. Zanganeh, H. Dashti, S. Ayatollahi, Visual investigation and modeling of asphaltene precipitation and deposition during $\mathrm{CO}_{2}$ miscible injection into oil reservoirs, Fuel, 160 (2015) 132-139.

[23] P. Zanganeh, H. Dashti, S. Ayatollahi, Comparing the effects of $\mathrm{CH}_{4}, \mathrm{CO}_{2}$, and $\mathrm{N}_{2}$ injection on asphaltene precipitation and deposition at reservoir condition: A visual and modeling study, Fuel, 217 (2018) 633-641.

[24] J.L. Creek, Freedom of action in the state of asphaltenes: Escape from conventional wisdom, Energy \& Fuels, 19 (2005) 1212-1224.

[25] A. Mirvakili, M.R. Rahimpour, A. Jahanmiri, Effect of a cationic surfactant as a chemical destabilization of crude oil based emulsions and asphaltene stabilized, Journal of Chemical \& Engineering Data, 57 (2012) 1689-1699.

[26] A. Yen, Y.R. Yin, S. Asomaning, Evaluating Asphaltene Inhibitors: Laboratory Tests and Field Studies, in: SPE International Symposium on Oilfield Chemistry, Society of Petroleum Engineers, Houston, Texas, 2001, pp. 7.

[27] L.M. Cenegy, Survey Of Successful World-wide Asphaltene Inhibitor Treatments In Oil Production Fields, in: SPE Annual Technical Conference and Exhibition, Society of Petroleum Engineers, New Orleans, Louisiana, 2001, pp. 7.

[28] M. Alhreez, D. Wen, Controlled releases of asphaltene inhibitors by nanoemulsions, Fuel, 234 (2018) 538-548.

[29] L.C. Rocha Junior, M.S. Ferreira, A.C. da Silva Ramos, Inhibition of asphaltene precipitation in Brazilian crude oils using new oil soluble amphiphiles, Journal of Petroleum Science and Engineering, 51 (2006) 26-36. 
[30] A.A. Cruz, M. Amaral, D. Santos, A. Palma, E. Franceschi, G.R. Borges, J.A.P. Coutinho, J.

509 Palácio, C. Dariva, CO2 influence on asphaltene precipitation, The Journal of Supercritical Fluids, 510143 (2019) 24-31.

511 [31] R.O. Idem, H.H. Ibrahim, Kinetics of $\mathrm{CO}_{2}$-induced asphaltene precipitation from various 512 Saskatchewan crude oils during $\mathrm{CO}_{2}$ miscible flooding, Journal of Petroleum Science and 513 Engineering, 35 (2002) 233-246.

514 [32] S. Kord, H. Dashti, P. Zanganeh, S. Ayatollahi, Evaluation of the kinetics of asphaltene 515 flocculation during natural depletion and $\mathrm{CO}_{2}$ injection in heptane-toluene mixtures, in, Society of 516 Petroleum Engineers, 2017.

517 [33] L.W. Lake, Fundamentals of Enhanced Oil Recovery, SPE, 1986.

518 [34] V. Alvarado, E. Manrique, Enhanced Oil Recovery: Field Planning and Development 519 Strategies, Elsevier Science, 2010.

520 [35] S.O. Olayiwola, M. Dejam, A comprehensive review on interaction of nanoparticles with low salinity water and surfactant for enhanced oil recovery in sandstone and carbonate reservoirs, Fuel, 241 (2019) 1045-1057.

[36] P. Rostami, M.F. Mehraban, M. Sharifi, M. Dejam, S. Ayatollahi, Effect of water salinity on oil/brine interfacial behaviour during low salinity waterflooding: A mechanistic study, Petroleum, (2019).

[37] V. Mashayekhizadeh, S. Kord, M. Dejam, EOR Potential within Iran, Special Topics \& Reviews in Porous Media: An International Journal, 5 (2014) 325-354.

[38] A. Al-Adasani, B. Bai, Recent developments and updated screening criteria of enhanced oil recovery techniques, in, Society of Petroleum Engineers, 2010.

[39] S.H. Talebian, R. Masoudi, I.M. Tan, P.L.J. Zitha, Foam assisted $\mathrm{CO}_{2}-\mathrm{EOR}$ : A review of concept, challenges, and future prospects, Journal of Petroleum Science and Engineering, 120 (2014) 202-215.

[40] B. Jia, J.-S. Tsau, R. Barati, A review of the current progress of CO2 injection EOR and carbon storage in shale oil reservoirs, Fuel, 236 (2019) 404-427.

[41] S.O. Olayiwola, M. Dejam, Mathematical modelling of surface tension of nanoparticles in electrolyte solutions, Chemical Engineering Science, 197 (2019) 345-356.

[42] E. Amirian, M. Dejam, Z. Chen, Performance forecasting for polymer flooding in heavy oil reservoirs, Fuel, 216 (2018) 83-100.

[43] H. Saboorian-Jooybari, M. Dejam, Z. Chen, Heavy oil polymer flooding from laboratory core floods to pilot tests and field applications: Half-century studies, Journal of Petroleum Science and Engineering, 142 (2016) 85-100.

[44] H. Saboorian-Jooybari, M. Dejam, Z. Chen, Half-Century of Heavy Oil Polymer Flooding from Laboratory Core Floods to Pilot Tests and Field Applications, in: SPE Canada Heavy Oil Technical Conference, Society of Petroleum Engineers, Calgary, Alberta, Canada, 2015, pp. 26. [45] H. Dashti, P. Zanganeh, S. Ayatollahi, The Comparison between Heavy and Light Oil Asphaltene Deposition during Pressure Depletion and $\mathrm{CO}_{2}$ Injection at Reservoir Condition, A Visual Laboratory Study, in: Chemeca 2013 - Brisbane, Engineers Australia, 2013.

[46] M. Cao, Y. Gu, Oil recovery mechanisms and asphaltene precipitation phenomenon in immiscible and miscible $\mathrm{CO}_{2}$ flooding processes, Fuel, 109 (2013) 157-166.

[47] T. Jafari Behbahani, C. Ghotbi, V. Taghikhani, A. Shahrabadi, Investigation of asphaltene adsorption in sandstone core sample during $\mathrm{CO}_{2}$ injection: Experimental and modified modeling, Fuel, 133 (2014) 63-72. 
[48] S. Kord, O. Mohammadzadeh, R. Miri, B.S. Soulgani, Further investigation into the mechanisms of asphaltene deposition and permeability impairment in porous media using a modified analytical model, Fuel, 117, Part A (2014) 259-268. [49] D.L. Gonzalez, E. Mahmoodaghdam, F.H. Lim, N.B. Joshi, Effects of gas additions to deepwater Gulf of Mexico reservoir oil: Experimental investigation of asphaltene precipitation and deposition, in, Society of Petroleum Engineers, 2012. [50] A.K.M. Jamaluddin, N. Joshi, F. Iwere, O. Gurpinar, An investigation of asphaltene instability under Nitrogen injection, in, Society of Petroleum Engineers, 2002. [51] Y. Kazemzadeh, R. Parsaei, M. Riazi, Experimental study of asphaltene precipitation prediction during gas injection to oil reservoirs by interfacial tension measurement, Colloids and Surfaces A: Physicochemical and Engineering Aspects, 466 (2015) 138-146. [52] S. Moradi, M. Dabiri, B. Dabir, D. Rashtchian, M.A. Emadi, Investigation of asphaltene precipitation in miscible gas injection processes: experimental study and modeling, Brazilian Journal of Chemical Engineering, 29 (2012) 665-676.

[53] S. Negahban, J.N.M. Bahamaish, N. Joshi, J. Nighswander, A.K.M. Jamaluddin, An experimental study at an Abu Dhabi reservoir of asphaltene precipitation caused by gas injection, (2005).

[54] N. Arsalan, S.S. Palayangoda, Q.P. Nguyen, Characterization of asphaltene deposition in a stainless steel tube, Journal of Petroleum Science and Engineering, 121 (2014) 66-77.

[55] T. Maqbool, A.T. Balgoa, H.S. Fogler, Revisiting asphaltene precipitation from crude oils: A case of neglected kinetic effects, Energy \& Fuels, 23 (2009) 3681-3686.

[56] T. Maqbool, S. Raha, M.P. Hoepfner, H.S. Fogler, Modeling the aggregation of asphaltene nanoaggregates in crude oil-precipitant systems, Energy \& Fuels, 25 (2011) 1585-1596.

[57] C.W. Angle, Y. Long, H. Hamza, L. Lue, Precipitation of asphaltenes from solvent-diluted heavy oil and thermodynamic properties of solvent-diluted heavy oil solutions, Fuel, 85 (2006) 492-506.

[58] R. Moghadasi, S. Kord, J. Moghadasi, H. Dashti, Mechanistic understanding of asphaltenes surface behavior at oil/water interface: An experimental study, Journal of Molecular Liquids, 285 (2019) 562-571.

[59] M. Jamialahmadi, B. Soltani, H. Müller-Steinhagen, D. Rashtchian, Measurement and prediction of the rate of deposition of flocculated asphaltene particles from oil, International Journal of Heat and Mass Transfer, 52 (2009) 4624-4634.

[60] B.S. Soulgani, B. Tohidi, M. Jamialahmadi, D. Rashtchian, Modeling formation damage due to asphaltene deposition in the porous media, Energy \& Fuels, 25 (2011) 753-761.

[61] F. Salimi, M.V. Seftie, S. Ayatollahi, Experimental investigation of the effects of different parameters on the rate of asphaltene deposition in laminar flow and its prediction using heat transfer approach, Journal of Dispersion Science and Technology, 34 (2013) 1690-1696.

[62] M. Haghshenasfard, K. Hooman, CFD modeling of asphaltene deposition rate from crude oil, Journal of Petroleum Science and Engineering, 128 (2015) 24-32.

[63] V.B.C. Fávero, A. Hanpan, P. Phichphimok, K. Binabdullah, H.S. Fogler, Mechanistic investigation of asphaltene deposition, Energy \& Fuels, (2016).

[64] A.K. Ghahfarokhi, P. Kor, R. Kharrat, B.S. Soulgani, Characterization of asphaltene deposition process in flow loop apparatus; An experimental investigation and modeling approach, Journal of Petroleum Science and Engineering, 151 (2017) 330-340. 
[65] J. Sayyad Amin, A. Alamdari, N. Mehranbod, S. Ayatollahi, E. Nikooee, Prediction of 598 asphaltene precipitation: Learning from data at different conditions, Energy \& Fuels, 24 (2010) 599 4046-4053.

600 [66] J. Sayyad Amin, S. Ayatollahi, A. Alamdari, Fractal characteristics of an asphaltene deposited 601 heterogeneous surface, Applied Surface Science, 256 (2009) 67-75.

602 [67] A.S.f.T.a. Materials, Annual Book of ASTM Standard, Philadelphia, PA, 2005.

603 [68] J.S. Amin, E.Nikooee, M.H. Ghatee, S. Ayatollahi, A. Alamdari, T. Sedghamiz, Investigating 604 the effect of different asphaltene structures on surface topography and wettability alteration, 605 Applied Surface Science, 257 (2011) 8341-8349.

606 [69] H. Dashti, S. Kord, A. Shariati, S. Ayatollahi, M. Moshfeghian, P. Zanganeh, Thermodynamic 607 Fluid Characterization of an Iranian Oil Reservoir, in: Near Surface 2011-17th EAGE European 608 Meeting of Environmental and Engineering Geophysics, Leicester, United Kingdom, 2011.

609 [70] L.X. Nghiem, B.F. Kohse, P.H. Sammon, Compositional simulation of the vapex process, in, 610 Petroleum Society of Canada, 2000.

611 [71] K. Rastegari, W.Y. Svrcek, H.W. Yarranton, Kinetics of Asphaltene Flocculation, Industrial 612 \& Engineering Chemistry Research, 43 (2004) 6861-6870.

613 [72] V.A.M. Branco, G.A. Mansoori, L.C. De Almeida Xavier, S.J. Park, H. Manafi, Asphaltene 614 flocculation and collapse from petroleum fluids, Journal of Petroleum Science and Engineering, $61532(2001) 217-230$.

616 [73] J.A. Duran, Y.A. Casas, L. Xiang, L. Zhang, H. Zeng, H.W. Yarranton, Nature of Asphaltene 617 Aggregates, Energy \& Fuels, (2018). 